\title{
Stability indicating RP-HPLC method for the estimation of Valsartan in pharmaceutical dosage form
}

\author{
M.Akiful Haque*, S.Hasan Amrohi, Prashanth Kumar.K, Nivedita.G, Pradeep \\ Kumar.T, Dibyalochan Mohanty and Prakash.V. Diwan \\ School of pharmacy, anurag group of institutions venkatapur, ghatkesar, \\ Hyderabad, Andhra Pradesh, India-501301.
}

\begin{abstract}
A simple, specific, accurate, precise and stability-indicating reverse phase high performance liquid chromatography (RP-HPLC) method is developed for estimation of Valsartan in tablet dosage form. The method employed, Phenomenox $C_{18}, 5 \mu m, 25 \mathrm{~cm} x 4.6 \mathrm{~mm}$ i.d. column in isocratic mode, with mobile phase of methanol \& phosphate buffer $\mathrm{pH} 3.0$ in ratio of 65:35(v/v). The flow rate was $1 \mathrm{~mL} \mathrm{~min}^{-1}$ and effluent was monitored at $210 \mathrm{~nm}$. Retention time was found to be $6.22 \mathrm{~min}$. The method was validated in terms of Linearity, accuracy, precision, limit of detection (LOD), limit of quantification (LOQ) etc. in accordance with ICH guidelines. Linear regression analysis data for the calibration plot showed that there was good linear relationship between response and concentration in the range of $10-100 \mu g / m l$ respectively. The LOD and $L O Q$ values for HPLC method were found to be 0.02 and $0.06 \mu \mathrm{g} / \mathrm{ml}$ respectively. No chromatographic interference from tablet excipients was found. The proposed method was successfully used for estimation of Valsartan in tablet dosage form.

Keywords-Valsartan, Reverse phase-High performance liquid chromatography (RP-HPLC).
\end{abstract}

\section{INTRODUCTION}

Valsartan is chemically 3-methyl-2- (pentanoyl-(4-(2-(2H-tetrazol-5-yl) phenyl) phenyl) methyl)amino)- butanoic acid (Fig. 1), angiotensin II receptor antagonist, acting on the AT1 subtype \& used for treatment of high blood pressure, of congestive heart failure, and post-myocardial infarction(MI). By blocking the action of angiotensin, valsartan dilates blood pressure. Methods such as HPLC, LC-MS , Protein precipitation, Capillary electrophoresis and Simultaneous UV-spectrophotometric methods are reported for estimation of Valsartan alone or on combination with other agents. However, there were few methods reported for determination of valsartan individually. The focus of present study was to develop \& validated a rapid, stable $\&$ economic HPLC method for the estimation in tablet dosage form.

\subsection{Chemicals and reagents:}

\section{MATERIALS AND METHODS}

Valsartan Active Pharmaceutical Ingredient (API) was provided by cipla laboratories, Goa. Methanol \& water of HPLC grade were from Standard reagents, Hyderabad. Commercial formulations of VALZAR-40 [Torrent pharmaceuticals] procured from Ahmadabad (GUJARAT).

\subsection{HPLC and Chromatographic conditions:}

The HPLC system employed was Shimadzu LC 2010c with PDA \& UV absorbance detector. The monitor \& processor was equipped with Winchrom softwar. Stationary phase used was Phenomenex $\mathrm{C}_{18}, 5 \mu \mathrm{m}$, $25 \mathrm{~cm} \times 4.6 \mathrm{~mm}$ i.d. column and the mobile phase was methanol and phosphate buffer in the ratio of $65: 35 \mathrm{v} / \mathrm{v}$ was used. The mobile phase was filtered using $0.45 \mu \mathrm{m}$ membrane filter. The mobile phase flow rate was $1 \mathrm{ml} / \mathrm{min}$ and injection volume was $20 \mu \mathrm{l}$.

\subsection{HPLC METHOD}

\subsubsection{STANDARD \& SAMPLE PREPARATION:}

The standard \& sample stock solutions were prepared separately by dissolving standard \& sample in a solvent mixture of methanol \& diluting with the same solvent.(After optimization of all conditions). HPLC spectrum of valsartan $(200 \mathrm{ppm})$ in optimized conditions is shown in Fig.2. 


\subsection{METHOD VALIDATION:}

\subsubsection{Accuracy: Recovery study:}

To determine the accuracy of the proposed method, recovery studies were carried out by adding different amounts $(80 \%, 100 \%$, and $120 \%)$ of pure drug of VALSARTAN were taken and added to the preanalyzed formulation of concentration $10 \mu \mathrm{g} / \mathrm{ml}$. From that percentage recovery values were calculated.

\subsubsection{Precision:} Repeatability

The precision of each method was ascertained separately from the peak areas \& retention times obtained by actual determination of five replicates of a fixed amount of drug. Valsartan (API) The percent relative standard deviation were calculated for valsartan are presented in the table.

Intra-assay \& inter-assay:

The intra \& inter day variation of the method was carried out $\&$ the high values of mean assay $\&$ low values of standard deviation \& $\%$ RSD ( $\%$ RSD $<2 \%$ ) within a day \& day to day variations for valsartan revealed that the proposed method is precise

\subsubsection{Linearity \& Range:}

The calibration curve showed good linearity in the range of $10-100 \mu \mathrm{g} / \mathrm{ml}$, for valsartan (API) with correlation coefficient $\left(\mathrm{r}^{2}\right)$ of 0.999 (Fig. 4). A typical calibration curve has the regression equation of $\mathrm{y}=$ $83907 x-78449$ for valsartan.

\subsubsection{Method Robustness:}

Influence of small changes in chromatographic conditions such as change in flow rate $( \pm$ $0.1 \mathrm{ml} / \mathrm{min})$, Temperature $\left( \pm 2^{0} \mathrm{C}\right)$, Wavelength of detection $( \pm 2 \mathrm{~nm})$ \& methanol content in mobile phase $( \pm 2 \%)$ studied to determine the robustness of the method are also in favour of (Table-4, \% RSD < 2\%) the developed RP-HPLC method for the analysis of valsartan ( API).

\subsubsection{LOD \& LOQ:}

The Minimum concentration level at which the analyte can be reliable detected (LOD) \& quantified (LOQ) were found to be $0.02 \& 0.06 \mu \mathrm{g} / \mathrm{ml}$ respectively.

\subsubsection{Specificity \& stability in analytical solution:}

The results of specificity indicated that the peak was pure in presence of degraded sample. It is important to mention here that the valsartan (API) was stable in solution form up to $24 \mathrm{hrs}$ at $25^{\circ} \mathrm{C}$.

The results of linearity, precision, inter \& intraday assays, method robustness, LOD, LOQ, specificity and stability in analytical solution established the validation of the developed RP-HPLC method for analysis of valsartan.

\subsection{ASSAY OF VALSARTAN IN DOSAGE FORM}

The assay of valzar and valtan tablets containing valsartan was found to be $100.88 \%$ and $98.18 \%$ as per the method.

\subsection{OPTIMIZATION OF CHROMATOGRAPHIC CONDITIONS:}

The chromatographic conditions were optimized by different means. (Using different column, different mobile phase, different flow rate, different detection wavelength $\&$ different diluents for sample preparation etc.

\section{PROCEDURE}

\section{STABILITY INDICATING STUDIES}

The API (Valsartan) was subjected to stress conditions in various ways to observe the rate and extent of degradation that is likely to occur in the course of storage and/or after administration to body. This is one type of accelerated stability studies that helps us determining the fate of the drug that is likely to happen after along time storage, within a very short time as compare to the real time or long term stability testing. The various degradation pathways studied are acid hydrolysis, basic hydrolysis, dry heat degradation, moist heat degradation, Photolytic degradation and oxidative degradation.

\subsection{ACID HYDROLYSIS:}

An accurately weighed $10 \mathrm{mg}$. of pure drug was transferred to a clean \& dry $10 \mathrm{ml}$ volumetric flask. To which $0.1 \mathrm{M}$ Hydrochloric acid was added \& make up to the mark \& kept for $24 \mathrm{hrs}$. from that $1 \mathrm{ml}$ was taken in to a $10 \mathrm{ml}$ volumetric flask \& make up to the mark with methanol, than injected into the HPLC system against a blank of $\mathrm{HCl} \&$ methanol ( after all optimized conditions ) 


\subsection{BASIC HYDROLYSIS}

An accurately weighed $10 \mathrm{mg}$. of pure drug was transferred to a clean \& dry $10 \mathrm{ml}$ volumetric flask. To which $0.1 \mathrm{M}$ Sodium hydroxide was added \& make up to the mark \& kept for $24 \mathrm{hrs}$. from that $1 \mathrm{ml}$ was taken in to a $10 \mathrm{ml}$ volumetric flask \& make up to the mark with methanol, than injected into the HPLC system against a blank of . $\mathrm{NaOH}$ and methanol (after all optimized conditions )

\subsection{OXIDATION WITH (3\%) $\mathrm{H}_{2} \mathrm{O}_{2}$ :}

An accurately weighed $10 \mathrm{mg}$. of pure drug was transferred to a clean \& dry $10 \mathrm{ml}$ volumetric flask. To which 3\% Hydrogen Peroxide was added, make up to the mark \& kept for 24 hrs. from that $1 \mathrm{ml}$ was taken in to a $10 \mathrm{ml}$ volumetric flask \& make up to the mark with methanol, than injected into the HPLC system against a blank of . $\mathrm{H}_{2} \mathrm{O}_{2}$ and methanol (after all optimized conditions )

\subsection{THERMAL DEGRADATION:}

An accurately weighed $10 \mathrm{mg}$. of pure drug was transferred to a clean \& dry $100 \mathrm{ml}$ volumetric flask, make up to the mark with methanol \& was maintained at $50{ }^{\circ} \mathrm{C}$. for $24 \mathrm{hrs}$. than injected into the HPLC system against a blank of methanol ( after all optimized conditions )

\subsection{PHOTOLYTIC DEGRADATION:}

Approximately $10 \mathrm{mg}$. of pure drug was taken in a clean \& dry Petridis. It was kept in a UV cabinet at $254 \mathrm{~nm}$ wavelength for 24 hours without interruption. Accurately weighed $1 \mathrm{mg}$. of the UV exposed drug was transferred to a clean \& dry $10 \mathrm{ml}$. volumetric flask. First the UV exposed drug was dissolved in methanol \& make up to the mark. than injected into the HPLC system against a blank of methanol ( after all optimized conditions ).

\section{Results of degradation studies:}

The results of the stress studies indicated the specificity of the method that has been developed. Valsartan was degraded only in $3 \% \mathrm{H}_{2} \mathrm{O}_{2}$ \& temperature stress conditions.

\section{RESULTS \& DISCUSSION}

To develop a precise, linear, specific \& suitable stability indicating RP-HPLC method for analysis of valsartan, different chromatographic conditions were applied \& the results observed are presented.

Isocratic elution is simple, requires only one pump \& flat baseline separation for easy and reproducible results. So, it was preferred for the current study over gradient elution.

In case of RP-HPLC various columns are available, but here Phenomenex , $\mathrm{C}_{18}, 5 \mu \mathrm{m}, 25 \mathrm{cmx} 4.6 \mathrm{~mm}$ i.d.. column was preferred because using this column peak shape, resolution and absorbance were good.

Mobile phase \& diluent for preparation of various samples were finalized after studying the solubility of API in different solvents of our disposal (methanol, acetonitrile, dichloromethane, water, $0.1 \mathrm{M}$ $\mathrm{NaOH}, 0.1 \mathrm{M} \mathrm{HCl})$.

The drug was found to be highly soluble in acetonitrile \& dichloromethane and methanol. Drug was insoluble in water. Using these solvents with appropriate composition newer methods can be developed and validated

Detection wavelength was selected after scanning the standard solution of drug over 200 to $800 \mathrm{~nm}$. (Fig. 29). From the U.V spectrum of racecadotril it is evident that most of the HPLC work can be accomplished in the wavelength range of $215-240 \mathrm{~nm}$ conveniently. Further, a flow rate of $0.5 \mathrm{ml} / \mathrm{min} \&$ an injection volume of $20 \mu \mathrm{l}$ were found to be the best analysis.

The result shows the developed method is yet another suitable method for assay and stability studies which can help in the analysis of valsartan in different formulations.

\section{CONCLUSION}

A sensitive \& selective RP-HPLC method has been developed \& validated for the analysis of Valsartan API. Further the proposed RP-HPLC method has excellent sensitivity, precision and reproducibility.

The result shows the developed method is yet another suitable method for assay, impurity studies which can help in the analysis of Valasartan in different formulations 


\section{REFERENCES}

[1]. 1. O' Neil MJ, Smith A, Heckelman PE, Kinneary JF, The Merck Index: An Encyclopedia of Chemicals, Drugs and Biologicals, $14^{\text {th }}$ Edn., 2006, 1767.

[2]. Matrindale-The Complete Drug Reference, $34^{\text {th }}$ Edn., Pharmaceutical Press, London, Chicago,

[3]. 2002, 1018 .

[4]. Kocyigit-Kaymacoglu B, Unsalan S and Rollas S., Determination and validation of Ketoprofen, Pantoprazole, and Valsartan together in human plasma by high performance liquid

[5]. schromatography, Pharmazie, 2006, 61,586-589.

[6]. Daneshtalab N, Lewanczuk RZ and Jamali F., High performance liquid chromatographic analysis of angiotensin-II receptor antagonist Valsartanusing a liquid extraction method, J Chromatogr B Analyt Technol Biomed Life Sci., 2002, 766,345- 359.

[7]. Gonzalez L, et al., Fast screening method for the determination of angiotensin II receptor

[8]. antagonists in human plasma by high-performance liquid chromatography with fluroimetric detection, J Chromatogr A, 2002, 949,49-60.

[9]. Koseki N, et al., Development and validation of a method for quantitative determination of

[10]. Valsartan in human plasma by liquid chromatography-tandem mass spectrometry,

[11]. Pharm Biomed Aanal., 2007, 43,1769-1774.

[12]. Li H, et al., A liquid chromatography/tandem mass spectrometry method for the simultaneous

[13]. quantification of Valsartan and Hydrochlorthiazide in human plasma. J Chromatogr B Analyt Technol Biomed Life Sci., 2007, $852,436-442$

[14]. Selvan PS, et al., Simultaneous determination of fixed dose combination of Nebivolol and Valsartan in human plasma by liquid chromatographictandem mass spectrometry and its application to pharmacokinetic study, J Chromatogr B Analyt Technol Biomed. Life Sci., 2007, 858,143-150.

[15]. 9. Macek J, Klima J and Ptacek P., Rapid determination of Valsartan in human plasma by protein precipitation and highperformance liquid chromatography, J Chromatogr B Analyt Technol Biomed Life Sci., 2006, 832,169-172.

[16]. Hillaert S and Bossche VW., Simultaneous determination of Hydrochlorthiazide and several

[17]. angiotensin-II receptor antagonists by capillary electrophoresis, J Pharm Biomed Anal., 2003,

[18]. 31,329-339.

[19]. Satana E, et al., Simultaneous determination of Valsartan and Hydrochlorthiazide in tablets by first-derivative ultraviolet spectrophotometry and LC, J Pharm Biomed Anal, 2001, 25,1009-1013.

[20]. Tatar S and Saglik S., Comparison of UV- and second derivative-spectrophotometric and LC

[21]. methods for the determination of Valsartan in pharmaceutical formulation, J Pharm Biomed

[22]. Anal., 2002, 30,371-375.

[23]. ICH. Q2B, Validation of analytical procedures methodology, In Proceedings of The International Conference on Harmonization, Geneva, 1993.

[24]. Sethi PD, HPLC quantitative analysis of pharmaceutical formulations, First Edn( Delhi,

[25]. CBS Publishers and distributers), 2001,11-160.

[26]. Krull, I., and swartz, M., Validation Viewpoint, Introduction: National and International

[27]. Guidelines, LC-GC. 1997, 15(6), 534-539.

[28]. United States Pharmacopoeia Validation of Compendial Methods, United States

[29]. Pharmacopoeia Convention, Rockville, 2007.

[30]. ASTM E Standard Guide for Conducting Ruggedness Tests (Plackett-Burman Design),

[31]. 1169-1189.

[32]. Plackett, R.L., and Burman, J.P., Biometrika. 1943, 33, 305-325.

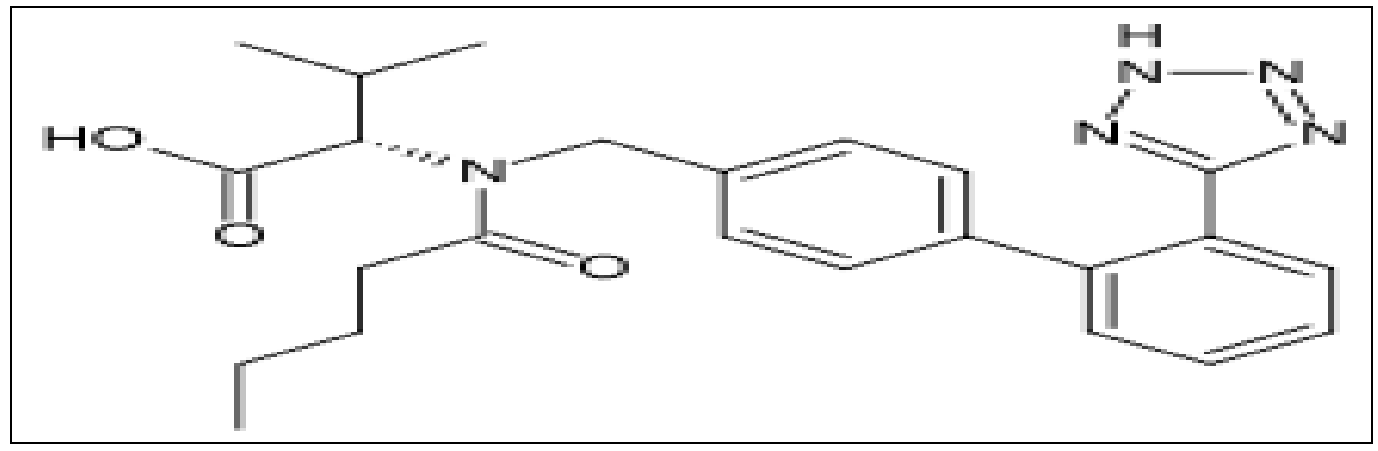

Fig.1: Structure of Valsartan 


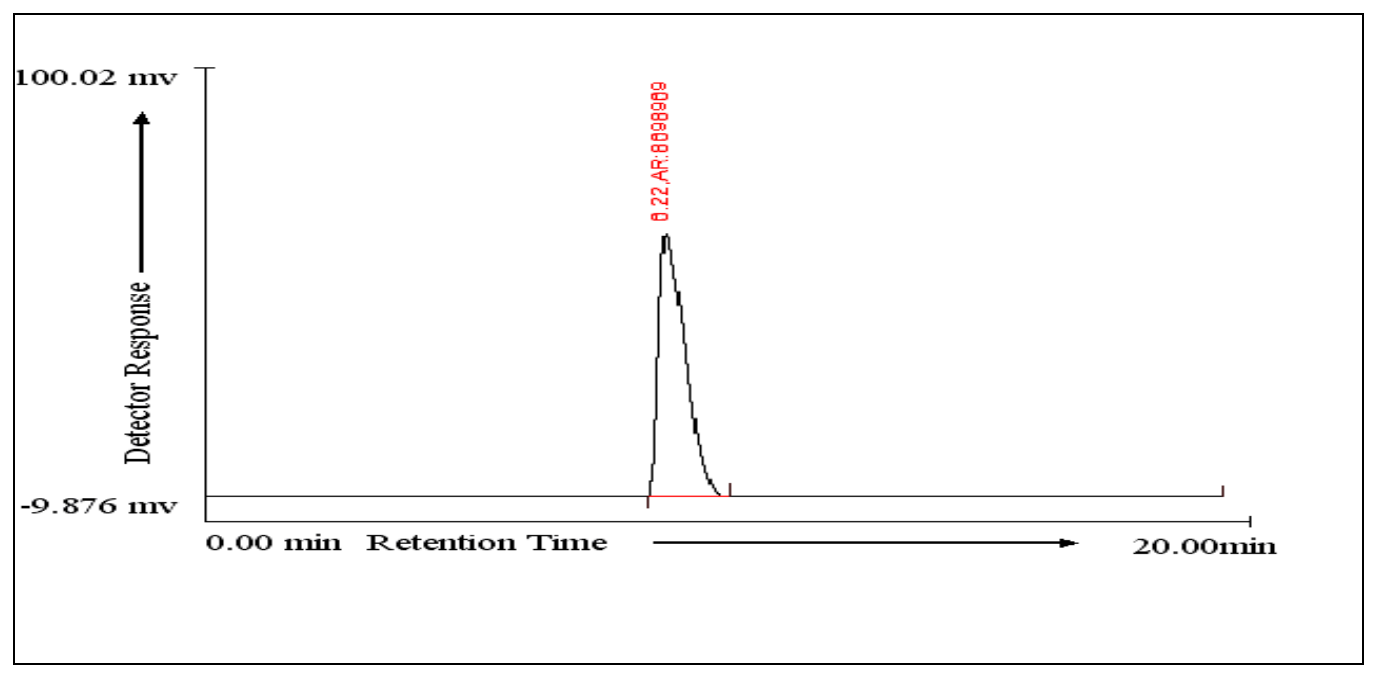

Fig.2: HPLC spectrum of valsartan $(200 \mathrm{ppm})$ in optimized conditions

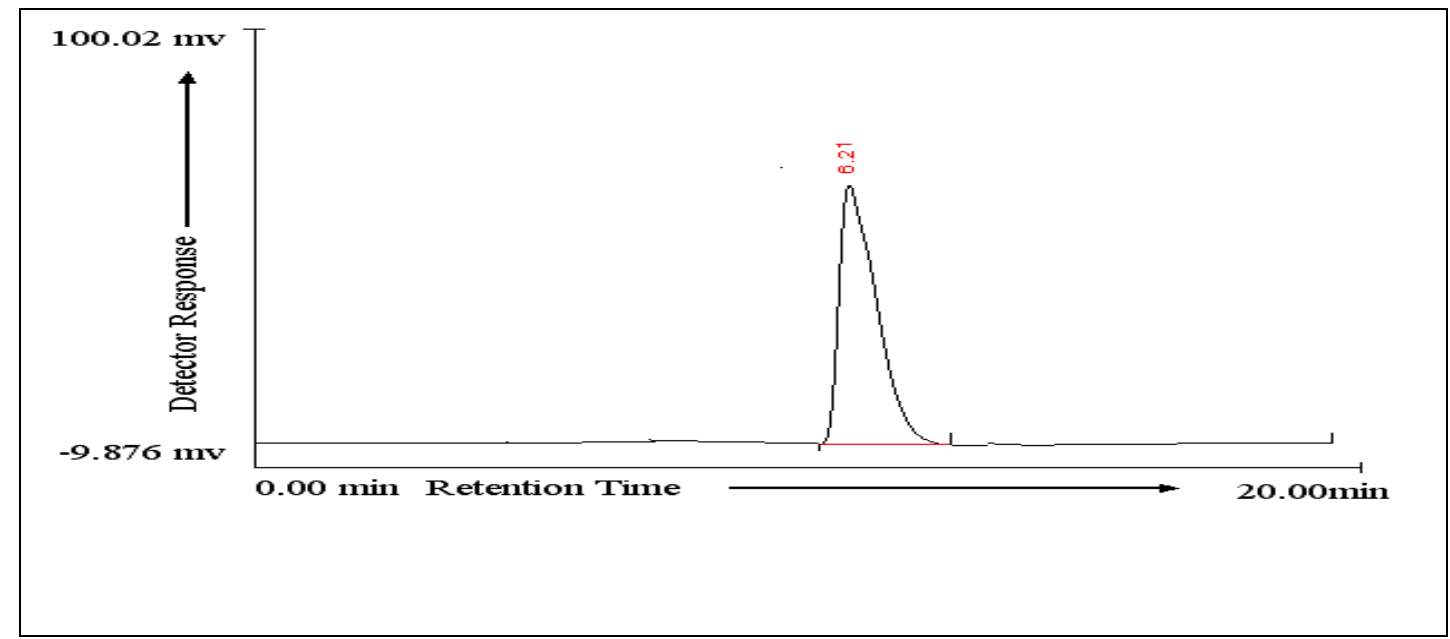

Fig.3: Chromatogram showing the degraded products in 0.1N Hcl

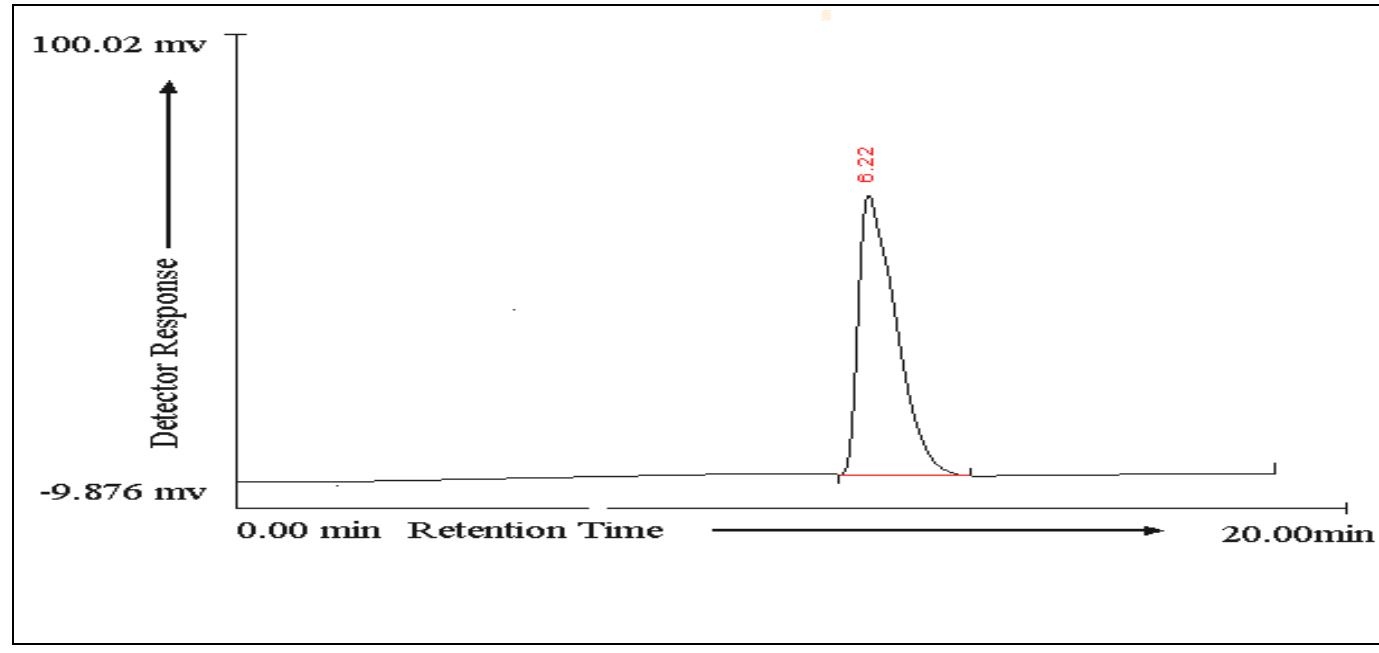

Fig.4: Chromatogram showing the degraded products in $0.1 \mathrm{~N} \mathrm{NaoH}$ 


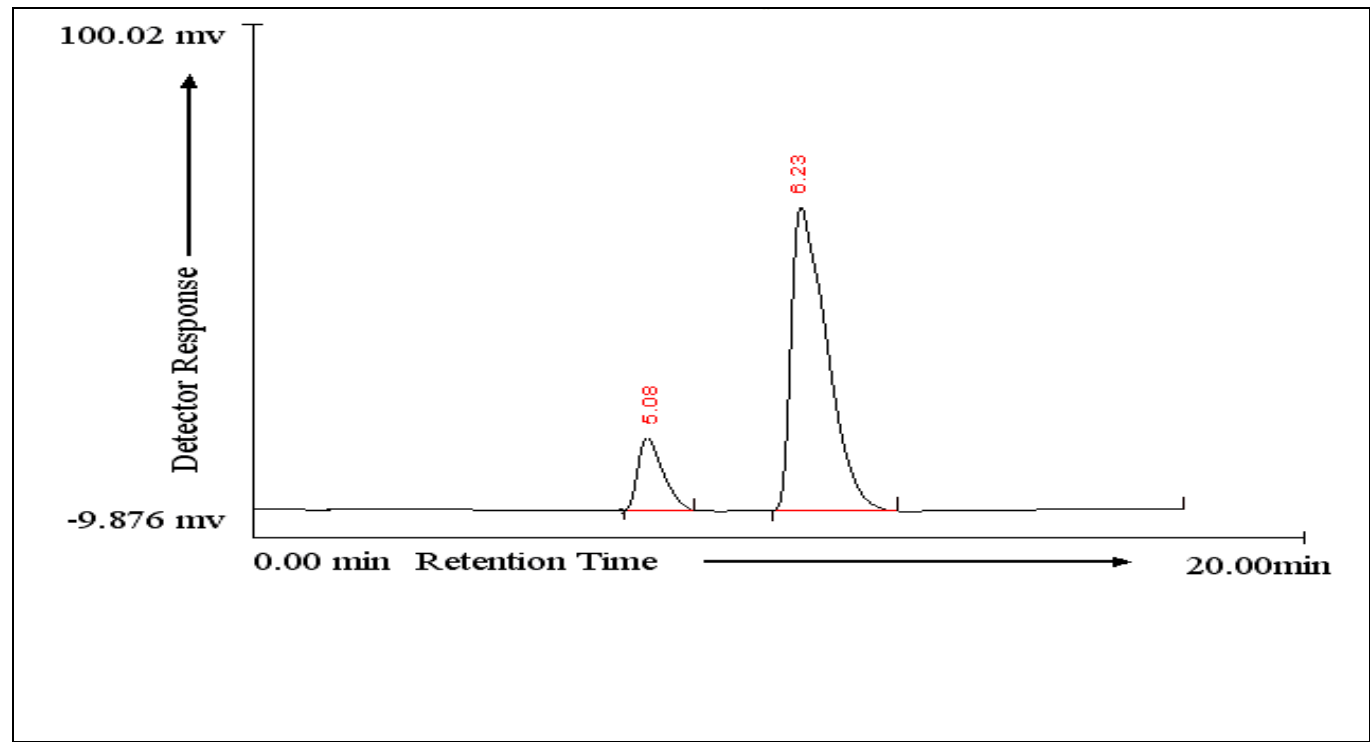

Fig.5: Chromatogram showing the degraded products after thermal degradation

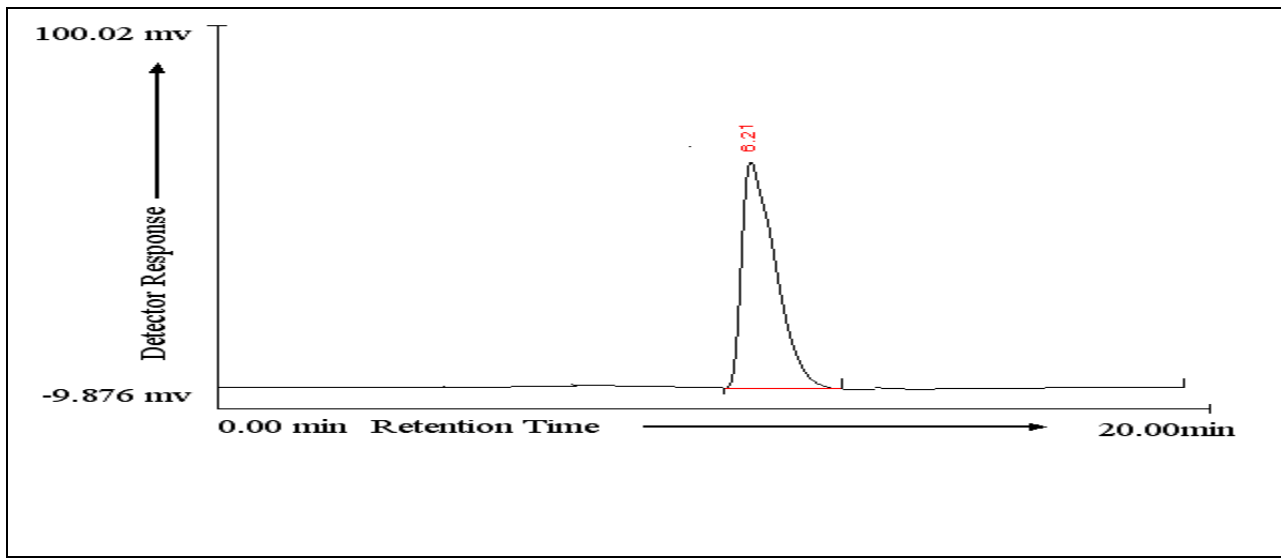

Fig.6: Chromatogram showing valsartan only (no degradation products) in photolytic studies.

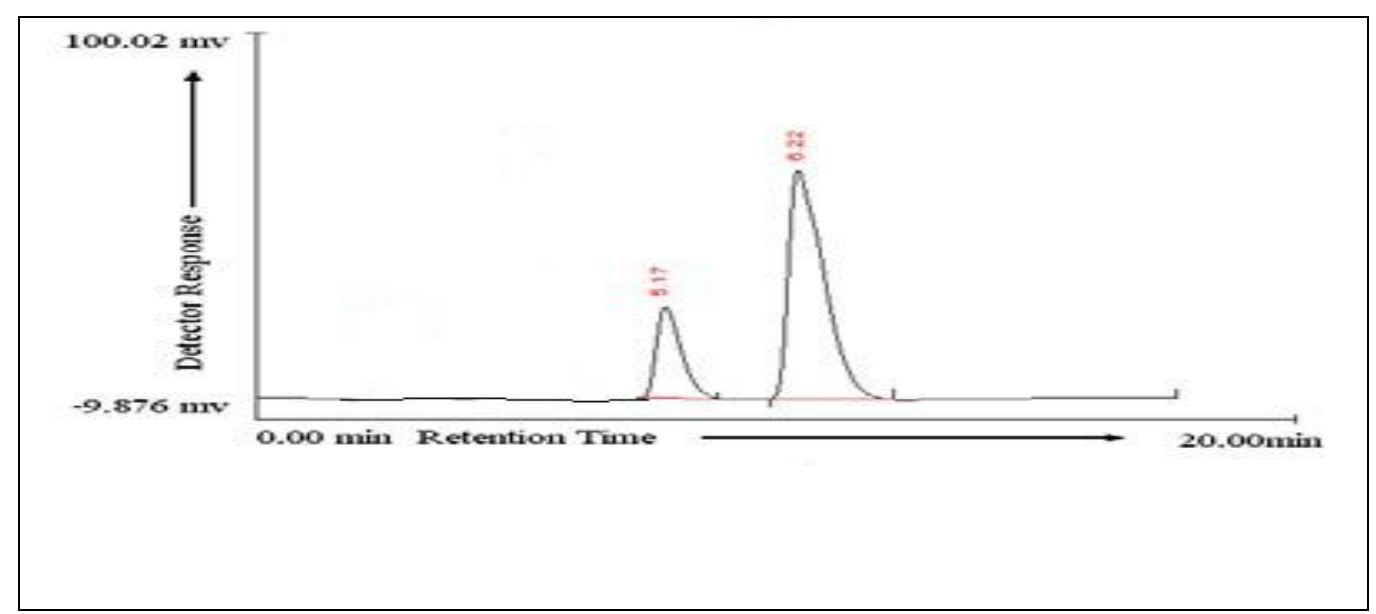

Fig.7: Chromatogram showing valsartan, degraded product in $\mathrm{H}_{2} \mathrm{O}_{2}$ 


\begin{tabular}{|c|c|c|c|c|}
\hline \multirow{2}{*}{ Sample ID } & \multicolumn{2}{|c|}{ Concentration $(\mu \mathrm{g} / \mathrm{ml})$} & \multirow{2}{*}{$\begin{array}{l}\% \text { Recovery of } \\
\text { Pure drug }\end{array}$} & \multirow{2}{*}{ Statistical Analysis } \\
\hline & Pure drug & Formulation & & \\
\hline $\mathrm{S}_{1}: 80 \%$ & 8 & 10 & 99.13 & \multirow{3}{*}{$\begin{array}{l}\text { Mean }=98.94667 \% \\
\text { S.D. }=0.171561 \\
\% \text { R.S.D. }=0.1733\end{array}$} \\
\hline $\mathrm{S}_{2}: 80 \%$ & 8 & 10 & 98.79 & \\
\hline $\mathrm{S}_{3}: 80 \%$ & 8 & 10 & 98.92 & \\
\hline $\mathrm{S}_{4}: 100 \%$ & 10 & 10 & 99.72 & \multirow{3}{*}{$\begin{array}{l}\text { Mean }=99.76 \% \\
\text { S.D. }=0.045826 \\
\text { \% R.S.D. }=0.0459\end{array}$} \\
\hline $\mathrm{S}_{5}: 100 \%$ & 10 & 10 & 99.81 & \\
\hline $\mathrm{S}_{6}: 100 \%$ & 10 & 10 & 99.75 & \\
\hline $\mathrm{S}_{7}: 120 \%$ & 12 & 10 & 99.36 & \multirow{3}{*}{$\begin{array}{l}\text { Mean }=99.37667 \% \\
\text { S.D. }=0.105987 \\
\% \text { R.S.D. }=0.1066\end{array}$} \\
\hline$S_{8}: 120 \%$ & 12 & 10 & 99.28 & \\
\hline $\mathrm{S}_{9}: 120 \%$ & 12 & 10 & 99.49 & \\
\hline
\end{tabular}

Table1: Results of recovery study

\begin{tabular}{|l|l|l|l|l|}
\hline \multirow{2}{*}{$\begin{array}{l}\text { Conc. } \\
\text { valsartan } \\
(\mu \mathrm{g} / \mathrm{ml})\end{array}$} & $\begin{array}{l}\text { Of } \\
\text { (API) }\end{array}$ & \multicolumn{4}{|l|}{ Observed Conc. Of valsartan $(\mu \mathrm{g} / \mathrm{ml})$ by the proposed method } \\
\cline { 2 - 5 } & Intra-Day & Inter-Day & Mean $(\mathrm{n}=6)$ & \% RSD \\
\cline { 2 - 5 } & Mean $(\mathrm{n}=6)$ & 0.86 & 10.03 & 0.87 \\
\hline 10 & 10.01 & 0.30 & 30.03 & 0.32 \\
\hline 30 & 30.02 & 0.13 & 99.95 & 0.11 \\
\hline
\end{tabular}

Table2: Results of intra-assay \& inter-assay

\begin{tabular}{|l|l|}
\hline Change in parameter & \% RSD \\
\hline Flow $(1.1 \mathrm{ml} / \mathrm{min})$ & 0.05 \\
\hline Flow $(0.9 \mathrm{ml} / \mathrm{min})$ & 0.06 \\
\hline Temperature $\left(27^{0} \mathrm{C}\right)$ & 0.04 \\
\hline Temperature $\left(21^{0} \mathrm{C}\right)$ & 0.04 \\
\hline Wavelength of Detection $(212 \mathrm{~nm})$ & 0.02 \\
\hline Wavelength of detection $(209 \mathrm{~nm})$ & 0.02 \\
\hline
\end{tabular}

Table3: Result of method robustness test

\begin{tabular}{|l|l|l|l|}
\hline Brand name of tablets & $\begin{array}{l}\text { Labeled amount of Drug } \\
(\mathrm{mg})\end{array}$ & $\begin{array}{l}\text { Mean ( } \pm \text { SD) amount } \\
(\mathrm{mg}) \text { found by the } \\
\text { proposed method }(\mathrm{n}=6)\end{array}$ & $\begin{array}{l}\text { Mean }( \pm \text { SD) Assay }(\mathrm{n}= \\
6\end{array}$ \\
\hline Valzar & $40.35( \pm 0.06)$ & $100.88( \pm 0.48)$ \\
\hline Valtan & 80 & $79.34( \pm 0.04)$ & $99.18( \pm 0.04)$ \\
\hline
\end{tabular}

Table4: Assay of valsartan capsules 